\title{
Molecular Size Diversity of Citrate Synthases from Pseudomonas Species
}

\author{
By COLIN G. MITCHELL AND P. D. J. WEITZMAN* \\ Department of Biochemistry, University of Bath, Bath BA2 7AY,UK
}

(Received 27 August 1985)

\begin{abstract}
Two forms of citrate synthase (EC 4.1.3.7) have been found in several species of Pseudomonas, a 'large' form $\left(M_{\mathrm{r}} \simeq 250000\right)$ which is generally inhibited by NADH and reactivated by AMP, and a 'small' form $\left(M_{\mathrm{r}} \simeq 100000\right)$ which is insensitive to these nucleotide effectors. Other species of Pseudomonas were found to contain either the 'large' or the 'small' form. Gel filtration and ion-exchange with the technique of fast protein liquid chromatography were used to resolve the enzymes. Where both citrate synthases were present, there did not appear to be an equilibrium between the two forms. The results reveal a new and complex diversity of citrate synthase within the genus Pseudomonas.
\end{abstract}

\section{INTRODUCTION}

As a result of studies on a wide range of organisms, two types of citrate synthase (EC 4.1.3.7) have been identified on the basis of molecular size (Weitzman, 1981). These are a 'large' form $\left(M_{\mathrm{r}} \simeq 250000\right)$ which occurs exclusively in Gram-negative bacteria and is generally inhibited by NADH, and a 'small' form $\left(M_{\mathrm{r}} \simeq 100000\right)$ which is found in Gram-positive bacteria and eukaryotes and is insensitive to NADH. This correlation has been used as a basis for the taxonomic classification of various organisms (Weitzman, 1980).

A mutant of Pseudomonas aeruginosa has recently been found to contain both a 'large' and a 'small' citrate synthase (Solomon \& Weitzman, 1983). Moreover, the relative proportions of the two forms changed with the phase of growth of the organism in batch culture; the 'large' form prednminated in exponential phase, whereas the 'small' form was the major component in stationary phase.

The occurrence of two citrate synthases in this mutant prompted us to investigate the possibility that other Pseudomonas species may also possess both forms of the enzyme. This communication reports our findings on the diversity of Pseudomonas citrate synthases as studied by the techniques of gel filtration and high resolution ion-exchange chromatography.

\section{METHODS}

Organisms used. The following organisms were kindly provided as indicated: Pseudomonas aeruginosa PAO 1 (Professor E. A. Dawes, Hull University, UK); P. aeruginosa 8602 and a mutant of this strain, PAC 514 (Professor P. H. Clarke, University College, London, UK); Pseudomonas acidovorans D 1870, Pseudomonas alcaligenes D 123, Pseudomonas chlororaphis D 302, Pseudomonas diminuta D 1032, Pseudomonas maltophilia D 144, Pseudomonas saccharophila D 1021 and Pseudomonas testosteroni D 1047 (Dr D. Jones, Leicester University, UK). Pseudomonas fluorescens D 1086, Pseudomonas putida NCIB 8296 and Pseudomonas stutzeri D 1022 were from our own laboratory culture collection.

Chemicals. Deoxyribonuclease, sodium pyruvate, AMP, NADH and 5,5'-dithiobis(2-nitrobenzoic acid) were from Sigma; coenzyme A, oxaloacetic acid and lactate dehydrogenase (rabbit muscle) were from Boehringer; Sephadex G-200 and DEAE-Sephacel were from Pharmacia. All other reagents used were analytical grade.

Preparation of cell extracts. Cells were grown to stationary phase $\left(16 \mathrm{~h}\right.$ ) at $37^{\circ} \mathrm{C}$ in $200 \mathrm{ml}$ nutrient broth (Oxoid) in $500 \mathrm{ml}$ flasks. The cells were harvested by centrifugation at $18000 \mathrm{~g}$ for $20 \mathrm{~min}$ at $4{ }^{\circ} \mathrm{C}$, resuspended in $2 \mathrm{ml}$

Abbreviation: FPLC, fast protein liquid chromatography. 
$20 \mathrm{mM}$-Tris $/ \mathrm{HCl}, \mathrm{pH} 7 \cdot 0$, containing $1 \mathrm{~mm}-\mathrm{EDTA}$ and $0 \cdot 1 \mathrm{M}-\mathrm{KCl}$, and sonicated for $4 \times 30 \mathrm{~s}$ bursts interspersed with $30 \mathrm{~s}$ periods of cooling at $4^{\circ} \mathrm{C}$. After centrifugation at $18000 \mathrm{~g}$ for $20 \mathrm{~min}$ at $4{ }^{\circ} \mathrm{C}$, the supernatant was fractionated as described below. In the case of $P$. maltophilia, a few crystals of DNAase were added after sonication to reduce the viscosity of the extract.

Gel filtration. Gel filtration was done at $4{ }^{\circ} \mathrm{C}$ on a column $(35 \times 2.5 \mathrm{~cm})$ of Sephadex G-200 equilibrated with $20 \mathrm{~mm}$-Tris/ $\mathrm{HCl}, \mathrm{pH} 7 \cdot 0$, containing $1 \mathrm{mM}$-EDTA and $0 \cdot 1 \mathrm{M}-\mathrm{KCl}$. Extract $(1 \mathrm{ml})$, to which had been added $50 \mu \mathrm{l}$ $(250 \mu \mathrm{g})$ of lactate dehydrogenase, was applied to the column; elution was done with the equilibration buffer and $2 \mathrm{ml}$ fractions were collected.

Ion-exchange chromatography. This was done on a column $(35 \times 2.5 \mathrm{~cm})$ of DEAE-Sephacel in $20 \mathrm{mM}-\mathrm{Tris} / \mathrm{HCl}$, pH 7.0 , containing $1 \mathrm{~mm}-\mathrm{EDTA}$ and $50 \mathrm{~mm}-\mathrm{KCl}$. Elution was achieved with a gradient of $\mathrm{KCl}(0 \cdot 05-0 \cdot 5 \mathrm{M}$; $500 \mathrm{ml}$ ) at a flow rate of $10 \mathrm{ml} \mathrm{h}^{-1} ; 5 \mathrm{ml}$ fractions were collected.

Ion-exchange chromatography using the fast protein liquid chromatography (FPLC) system (Pharmacia) was done at $23^{\circ} \mathrm{C}$. The strong anionic exchanger Mono $\mathrm{Q}$ was used in a column (HR 5/5) of $1 \mathrm{ml}$ bed volume. The column was equilibrated with $20 \mathrm{~mm}-1,3-$ bis[tris(hydroxymethyl)methylamino]propane/ $\mathrm{HCl}, \mathrm{pH} 7 \cdot 0$. Before application to the column, samples were treated with $1 \mathrm{mg}$ protamine sulphate per $10 \mathrm{mg}$ of protein, the mixture stirred on ice for $20 \mathrm{~min}$ and then centrifuged at $18000 \mathrm{~g}$ for $20 \mathrm{~min}$. The supernatant was diluted 10 -fold with $20 \mathrm{~mm}$-Tris/ $\mathrm{HCl}, \mathrm{pH} 7 \cdot 0$, containing $1 \mathrm{~mm}$-EDTA, and filtered through a $0.45 \mu \mathrm{m}$ Millipore filter. The sample was applied to the column and washed with $10 \mathrm{ml}$ starting buffer. Protein was eluted with either $25 \mathrm{ml}$ of a $0-0 \cdot 2 \mathrm{M}-\mathrm{KCl}$ gradient or $78 \mathrm{ml}$ of a $0-0.5 \mathrm{M}-\mathrm{KCl}$ gradient at a flow rate of 1 or $1.5 \mathrm{ml} \mathrm{min}$ m $^{-1}$ respectively. The enzymes of $P$. acidovorans, $P$. saccharophila and $P$. stutzeri were eluted using the latter gradient; all other citrate synthases were eluted with the former. Protein was monitored by the absorbance at $280 \mathrm{~nm}$.

Enzyme assays. Citrate synthase and lactate dehydrogenase were assayed as previously described (Weitzman \& Dunmore, 1969). Protein was estimated by the Lowry method.

\section{RESULTS AND DISCUSSION}

\section{Resolution of two distinct citrate synthases by gel filtration}

The presence of two distinct citrate synthases in a mutant of $P$. aeruginosa, designated PAC 514 (formerly At 14; Skinner \& Clarke, 1968), has been reported by Solomon \& Weitzman (1983) together with the growth-dependent variation in the proportions of the two isoenzymes. We, therefore, initially examined the parent strain of this mutant, $P$. aeruginosa 8602 , for the presence of the two enzymes. Gel filtration of stationary-phase cell extracts showed that both forms were present. However, unlike the mutant, the relative proportions of the two did not appear to vary at different stages of growth. This prompted an investigation of other strains of $P$. aeruginosa, as well as other Pseudomonas species, to determine whether the possession of two citrate synthases is a general characteristic of pseudomonads.

Crude cell extracts were subjected to gel filtration on Sephadex G-200 using lactate dehydrogenase $\left(M_{\mathrm{r}} \simeq 140000\right)$ as a marker protein. As previously reported (Weitzman \& Dunmore, 1969; Solomon \& Weitzman, 1983) the 'large' form of citrate synthase is eluted before lactate dehydrogenase, whereas the 'small' enzyme is eluted after the marker. The results are summarized in Table 1. The presence of 'large' and 'small' citrate synthases is not restricted to the one strain of $P$. aeruginosa. Other strains of $P$. aeruginosa, as well as $P$. fluorescens, $P$. putida and $P$. stutzeri, all contain both isoenzymes.

Pseudomonads may be classified into five groups on the basis of RNA homology (Palleroni, 1978). Group I contains both fluorescent and non-fluorescent members as $P$. fluorescens and $P$. stutzeri; group II consists of pathogenic species such as $P$. cepacia; group III is a rather phenotypically heterogeneous group, a representative of which is $P$. acidovorans; group IV is represented by $P$. diminuta, and group V, a relatively poorly understood group, is represented by P. maltophilia.

Those pseudomonads possessing both citrate synthases appear to be restricted to RNA homology group I. The exceptions in the group, $P$. alcaligenes and $P$. chlororaphis, both have a 'small' citrate synthase. Representatives of the other RNA homology groups possess a single citrate synthase, either 'large' or 'small'. Group II organisms were not studied, as they are all pathogenic. Fig. 1 shows a gel filtration profile for a representative from each of the three types found: $P$. fluorescens ('large' and 'small' citrate synthases), $P$. saccharophila ('small' enzyme) and $P$. testosteroni ('large' enzyme). 
Table 1. Distribution of 'large' and 'small' citrate synthases in Pseudomonas species

\begin{tabular}{|c|c|c|c|c|}
\hline \multirow[b]{2}{*}{ Organism* } & \multirow{2}{*}{$\begin{array}{l}\text { RNA } \\
\text { homology } \\
\text { group }\end{array}$} & \multirow{2}{*}{$\begin{array}{l}\text { Size of } \\
\text { citrate } \\
\text { synthase }\end{array}$} & \multicolumn{2}{|c|}{$\begin{array}{l}\text { Percentage of 'small' } \\
\text { citrate synthase } \ddagger\end{array}$} \\
\hline & & & Gel filtration & FPLC \\
\hline P. aeruginosa NCIB 8295 & & $\mathrm{~L}+\mathrm{S}$ & 14 & 21 \\
\hline P. aeruginosa 8602 & & $\mathrm{~L}+\mathrm{S}$ & 6 & 18 \\
\hline P. aeruginosa PAC 514 & & $\mathrm{~L}+\mathrm{S}$ & 90 & 98 \\
\hline$P$. aeruginosa $\mathrm{PAO} 1$ & & $\mathrm{~L}+\mathrm{S}$ & 16 & NT \\
\hline$P$. fluorescens & I & $\mathrm{L}+\mathrm{S}$ & 25 & 25 \\
\hline P. putida & & $\mathrm{L}+\mathrm{S}$ & 21 & 22 \\
\hline P. stutzeri & & $\mathrm{L}+\mathrm{S}$ & 31 & 23 \\
\hline$P$. alcaligenes & & S & & \\
\hline P. chlororaphis & & $\mathrm{S}$ & & \\
\hline P. acidovorans & & $\mathrm{L}$ & & \\
\hline P. saccharophila & III & $\mathbf{S}$ & & \\
\hline P. testosteroni & & $\mathbf{L}$ & & \\
\hline P. diminuta & IV & $\mathrm{L}$ & & \\
\hline P. maltophilia & V & $\dot{s}$ & & \\
\hline
\end{tabular}

NT, Not tested.

* Bacterial strain numbers are given in Methods.

$+\mathrm{L}$ and $\mathrm{S}$ denote "large" and 'small" citrate synthase respectively.

$\ddagger$ The percentage of 'small' citrate synthase in the total citrate synthase was calculated from the elution peak areas after gel filtration on Sephadex G-200 or from the separate activities obtained by FPLC.

The separated citrate synthase isoenzymes were tested for sensitivity to inhibition by NADH and reactivation by AMP. All the 'small' citrate synthases were found to be unaffected by NADH and AMP. The 'large' enzymes were inhibited by NADH and reactivated by AMP, with the exception of the citrate synthase from $P$. testosteroni, which was unaffected by both nucleotides. This insensitivity of a 'large' citrate synthase to inhibition by NADH has also been observed with Acetobacter spp. (Weitzman, 1981).

The proportion of the total citrate synthase activity which may be accounted for by the 'small' enzyme varies between the different pseudomonads. A proportion of $6 \%$ was found with $P$. aeruginosa 8602 but $31 \%$ with $P$. stutzeri. The very high proportion of 'small' enzyme in the mutant $P$. aeruginosa PAC 514 arises from the growth-dependent variation and the fact that the bacteria were harvested in stationary phase (Solomon \& Weitzman, 1983). In the case of those pseudomonads which possess both citrate synthases, a second gel filtration of the separated 'large' and 'small' isoenzymes resulted in each form again behaving as a single enzyme species. An association-dissociation system therefore seems unlikely to account for the presence of the two enzymes and it is presumed that the two distinct citrate synthases occur in vivo.

\section{Resolution of two distinct citrate synthases by ion-exchange fast protein liquid chromatography}

Further evidence for the presence of two citrate synthases in some pseudomonads has been gained from ion-exchange chromatography using the recently introduced technique of fast protein liquid chromatography (FPLC). We have previously shown that this new separation method may be used successfully to effect speedy separation of isoenzymes of citrate synthase and isocitrate dehydrogenase with a degree of resolution greater than that achieved by conventional ion-exchange procedures (Mitchell et al., 1986).

Fig. 2 shows the elution profile of citrate synthase from $P$. aeruginosa PAC 514 following ionexchange chromatography on DEAE-Sephacel. The isoenzymes were eluted as an apparently single peak of activity. However, the first two fractions collected were stimulated by $1 \mathrm{mM}-$ AMP, a characteristic property of the 'large' citrate synthase from this organism (Solomon \& Weitzman, 1983), whereas the remaining fractions were not stimulated by AMP. That both 


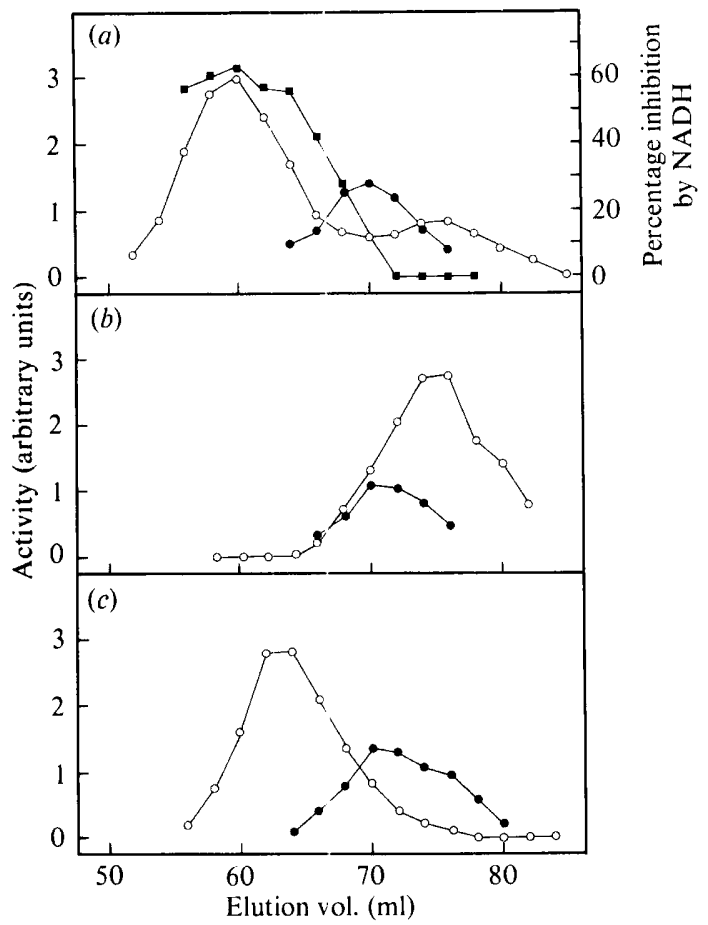

Fig. 1. Gel filtration of citrate synthases from (a) P. fluorescens, (b) $P$. saccharophila and $(c) P$. testosteroni. $\bigcirc$, Citrate synthase activity;, lactate dehydrogenase activity; $\boldsymbol{\varphi}$, percentage inhibition of citrate synthase by $1 \mathrm{~mm}-\mathrm{NADH}$. Enzyme activities are in arbitrary units. Specific activities of the peak fractions were as follows $\left[\mu \mathrm{mol} \mathrm{min}^{-1}(\mathrm{mg} \text { protein })^{-1}\right]:(a)$ first peak $0 \cdot 70$, second peak $0 \cdot 22 ;(b)$ 0.84 ; and $(c) 1 \cdot 6$.

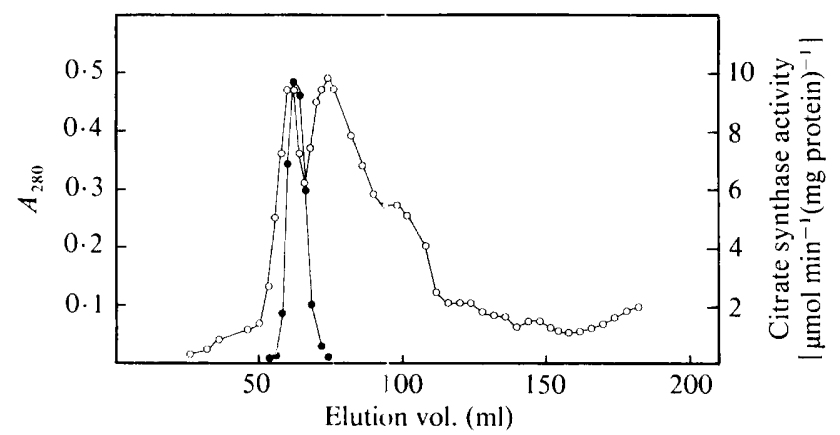

Fig. 2. Elution profile of $P$. aeruginosa PAC 514 citrate synthase from DEAE-Sephacel. $\bigcirc$, Absorbance at $280 \mathrm{~nm} ;(\mathcal{O})$, citrate synthase activity.

'large' and 'small' isoenzymes were present was shown by subjecting the extract to chromatography using FPLC (Fig. 3). This experiment also demonstrates the higher resolving power of which the FPLC system is capable.

The resolution of the 'large' and 'small' citrate synthases from the other species using FPLC is shown in Fig. 4. However, the degree of resolution varies. For example, the citrate synthase isoenzymes of $P$. fluorescens and $P$. stutzeri were eluted much closer together than those of $P$. putida. The 'small' isoenzymes were eluted before the 'large', except in the case of $P$. stutzeri. In 


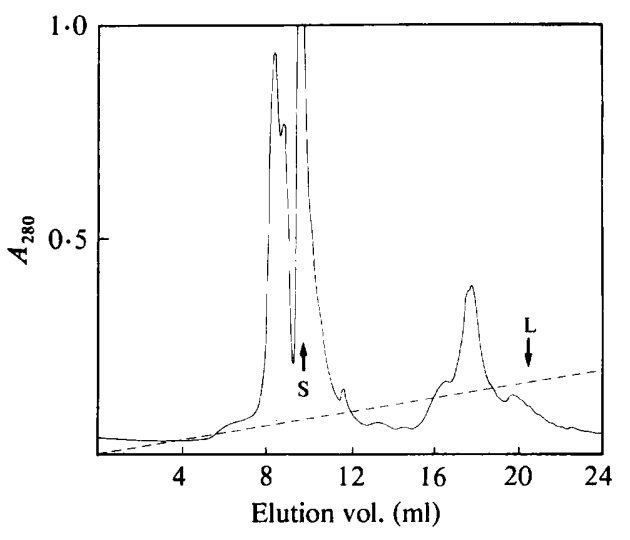

Fig. 3

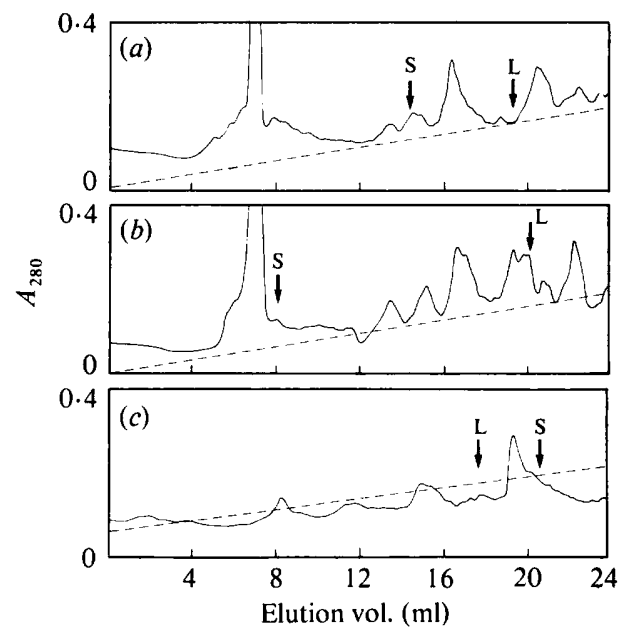

Fig. 4

Fig. 3. Elution profile of $P$. aeruginosa PAC 514 citrate synthase from Mono Q using FPLC. Elution conditions are described in the text. $\mathrm{L}$ and $\mathrm{S}$ denote 'large' and 'small' citrate synthase respectively.

Fig. 4. Elution profiles of (a) P. fluorescens, (b) P. putida and (c) P. stutzeri citrate synthases from Mono $\mathrm{Q}$ using FPLC. Elution conditions are described in the text. L and $\mathrm{S}$ denote 'large' and 'small' citrate synthase respectively.

contrast, $P$. saccharophila and $P$. acidovorans were shown by gel filtration to possess only the 'small' or the 'large' enzyme respectively; each gave rise to a single peak of activity by FPLC analysis.

The proportion of the 'small' isoenzyme calculated from the total activity eluted from the FPLC column was within the range $18-23 \%$, values not dissimilar to those calculated from the gel filtration experiments (Table 1).

It had previously been thought that all prokaryotic and eukaryotic cells contained a single form of citrate synthase, either 'large' or 'small'. Two forms of the enzyme were reported in studies of a marine pseudomonad (Massarini \& Cazzulo, 1975; Higa et al., 1978) but their ready interconversion in vitro leaves the question of their in vivo existence uncertain. An equilibrium of different oligomeric states of Escherichia coli citrate synthase has also been demonstrated (Wright \& Sanwal, 1971; Danson \& Weitzman, 1973). The situation described by Solomon \& Weitzman (1983) for the $P$. aeruginosa mutant is quite different. The absence of interconversion of the two forms of the enzyme, coupled with their growth-dependent variation, strongly suggests their independent existence in vivo. The present study has shown that two forms of citrate synthase occur in other pseudomonads, though perhaps only those in RNA homology group I. The variation of enzyme complement within a single genus is rather unexpected and its physiological significance, together with that of the occurrence of the two enzymes, is the subject of continuing investigations.

We thank Professor Dawes, Professor Clarke and Dr Jones for kindly providing cultures of Pseudomonas species, and the Science and Engineering Research Council for financial support (Grant GR/C/36377). We also gratefully acknowledge support from The Royal Society in the form of a Scientific Investigations Grant to purchase the FPLC equipment.

\section{REFEREINCES}

Danson, M. J. \& Weitzman, P. D. J. (1973) Functional groups in the activity and regulation of Escherichia coli citrate synthase. Biochemical Journal 135, 513-524.
Higa, A. I., Massarini, E. \& Cazzulo, J. J. (1978). Purification and some properties of the citrate synthase from a marine Pseudomonas. Canadian Journal of Microbiology 24, 215-221. 
Massarini, E. \& Cazzulo, J. J. (1975). Two forms of citrate synthase in a marine pseudomonad. FEBS Letters 57, 134-138.

Mitchell, C. G., O'Neil, S., Reeves, H. C. \& Weitzman, P. D. J. (1986). Isoenzyme separation by fast protein liquid chromatography. FEBS Letters (in the Press).

Palleroni, N. J. (1978). Patterns of Progress - The Pseudomonas Group. Shildon, UK: Meadowfield Press.

Skinner, A. J. \& Clarke, P. H. (1968). Acetate and acetamide mutants of Pseudomonas aeruginosa 8602 . Journal of General Microbiology 50, 183-194.

Solomon, M. \& Weitzman, P. D. J. (1983). Occurrence of two distinct citrate synthases in a mutant of Pseudomonas aeruginosa and their growth-dependent variation. FEBS Letters 155, 157-160.
Weitzman, P. D. J. (1980). Citrate synthase and succinate thiokinase in classification and identification. In Microbiological Classification and Identification, pp. 107-125. Edited by M. Goodfellow \& R. G. Board. London \& New York: Academic Press.

WeITZMAN, P. D. J. (1981). Unity and diversity in some bacterial citric acid cycle enzymes. Advances in Microbial Physiology 22, 185-244.

Weitzman, P. D. J. \& Dunmore, P. (1969). Citrate synthases: allosteric regulation and molecular size. Biochimica et biophysica acta 171, 198-200.

WRIGHT, J. A. \& SANWAL, B. D. (1971). Regulatory mechanisms involving nicotinamide adenine nucleotides as allosteric effectors. IV. Physicochemical study and binding of ligands to citrate synthase. Journal of Biological Chemistry 246, 1689-1699. 